\title{
IMPLEMENTASI KEBIJAKAN KEPALA PASAR \\ DALAM PROGAM K3 (KEBERSIHAN, KEAMANAN DAN KETERTIBAN) DI PERUSAHAAN DAERAH PASAR PAKUAN JAYA KOTA BOGOR
}

\author{
POLICY IMPLEMENTATION OF THE HEAD OF MARKET \\ IN THE PROGRAM K3 (HYGIENE, SAFETY AND ORDER) \\ IN THE COMPANY OF MARKET FERNS JAYA CITY BANDUNG
}

\begin{abstract}
Adi Mandala Louhenapessy, Dr. H. Chairul Amri, SH., M.Si², Ginung Pratidina, Dra., M.Si ${ }^{3}$
${ }^{1}$ Jurusan Ilmu Administrasi Negara Fakultas Ilmu Sosial dan Ilmu Politik Universitas Djuanda, Jl. Tol Ciawi No. 1, Kotak Pos 35 Bogor 16720.

${ }^{2}$ Jurusan Ilmu Administrasi Negara Fakultas Ilmu Sosial dan Ilmu Politik Universitas Djuanda, Jl. Tol Ciawi No. 1, Kotak Pos 35 Bogor 16720.

${ }^{3}$ Jurusan Ilmu Administrasi Negara Fakultas Ilmu Sosial dan Ilmu Politik Universitas Djuanda, Jl. Tol Ciawi No. 1, Kotak Pos 35 Bogor 16720.

Korespondensi: Adi Mandala Louhenapessy.
\end{abstract}

(Diterima oleh Dewan Redaksi: 01-08-2015)

(Dipublikasikan oleh Dewan Redaksi: 01-10-2015)

\begin{abstract}
Control of street vendors in Kebun Flower Market is still not optimal, it can be seen still occur kesemerawutan, untidiness and traffic congestion. In the implementation of program policies K3, influenced by factors such success standards and policy objectives, resource policies, communication between the organization and implementation of the activities, characteristics agency / implementing agency policies, attitudes implementing policies, socio-economic conditions and politik.Tujuan research conducted is to know the implementation of K3, K3 and program barriers K3 program at the Company's efforts Pasar Jaya Pakuan Bogor. The research method using descriptive and qualitative approach. The results of market research head of policy implementation in which the implementation of the program K3 K3 picket system, controlling the implementation of a merchant, the implementation of hygiene supervision, implementation of the billing service charge, and coordination with the village, and babinmas babinsa.
\end{abstract}

Key Words : implementation Policy, Head of Markets, K3 Program

\begin{abstract}
ABSTRAK
Penertiban PKL di Pasar Kebon Kembang masih belum optimal, hal ini dapat dilihat masih terjadi kesemerawutan, kekumuhan serta kemacetan lalu lintas. Dalam implementasi kebijakan program K3, dipengaruhi oleh faktor-faktor keberhasilan seperti standar dan tujuan kebijakan, sumber daya kebijakan, komunikasi antar organisasi dan aktivitas pelaksanaan, karakteristik badan/instansi pelaksana kebijakan, sikap pelaksana kebijakan, kondisi sosial ekonomi dan politik.Tujuan penelitian yang dilakukan adalah untuk mengetahui implementasi program K3, hambatan program K3 dan upaya program K3 di Perusahaan Daerah Pasar Pakuan Jaya Kota Bogor. Metode penelitian mengg unakan penelitian deskriptif dan pendekatan kualitatif. Hasil penelitian Implementasi kebijakan kepala pasar dalam program K3 yaitu pelaksanaan sistem piket K3, pelaksanaan
\end{abstract}


penertiban pedagang, pelaksanaan supervisi kebersihan, pelaksanaan penagihan service charge, dan pelaksanaan koordinasi dengan pihak kelurahan, babinsa dan babinmas.

Kata Kunci : Implementasi Kebijakan, Kepala Pasar, Program K3.

Mandala L., Adi. 2015. Implementasi Kebijakan Kepala Pasar dalam Program K3 (Kebersihan, Keamanan dan Ketertiban) di Perusahaan Daerah Pasar Pakuan Jaya Kota Bogor. Jurnal Sosial Humaniora 2(2): 209 - 220. 


\section{PENDAHULUAN}

Kota Bogor memiliki sebanyak 7 (tujuh) pasar yaitu Pasar Baru Bogor, Pasar Kebon Kembang, Pasar Merdeka, Pasar Sukasari, Pasar Jambu Dua, Pasar Gunung Batu dan Pasar Padasuka. Pada tahun 2009, dalam rangka meningkatkan pelayanan kepada masyarakat dalam bidang perdagangan, khusunya pengelolaan pasar, Pemerintah Kota Bogor mengeluarkan Peraturan Daerah Nomor 4 Tahun 2009 tentang Pendirian Perusahaan Daerah Pasar Pakuan Jaya Kota Bogor, pendirian perusahaan daerah ini menjadi sumber Pendapatan Asli Daerah untuk menunjang pembangunan daerah. Berdasarkan Peraturan Daerah Kota Bogor Nomor 4 Tahun 2009 tentang Perusahaan Daerah Pasar Pakuan Jaya, PD Pasar Pakuan Jaya Kota Bogor adalah Perusahaan Daerah yang mengelola pasar milik pemerintah.

Dalam pengelolaan pasar, sebuah pasar dipimpin oleh seorang Kepala Pasar. Kepala Pasar adalah kepala unit yang mempunyai tugas pokok dan fungsi di bidang perpasaran yang diangkat oleh direksi. Dalam Peraturan Direksi PD Pasar Pakuan Jaya No. 1.2.1 Tahun 2012 tentang Tugas Pokok dan Fungsi serta Uraian Jabatan di Lingkungan Perusahaan Daerah Pasar Pakuan Jaya Kota Bogor pada Pasal 31 Bagian Keenam, Tugas Pokok dan Fungsi Kepala Pasar sebagai pelaksana teknis program kerja operasional Perusahaan Daerah yang mempunyai wilayah tertentu yang dipimpin oleh Kepala Unit. Dalam melaksanakan tugasnya kepala unit pasar dibantu oleh staf unit dan bertanggung jawab kepada Direksi.

Berdasarkan hasil observasi, maka implementasi kebijakan kepala pasar belum maksimal, yang dapat dilihat dari :

1. Penataan Pedagang Kaki Lima (PKL) yang belum optimal.

Keberadaan Pedagang Kaki Lima (PKL) mengakibatkan kesemrawutan dan kekumuhan serta kemacetan. Begitu pun keberadaan PKL di Pasar Kebon Kembang. Berdasarkan data pedagang kaki lima yang dapat dilihat pada tabel berikut :

Tabel 1. Jumlah Pedagang Kaki Lima

\begin{tabular}{|c|c|c|}
\hline NO & PASAR & JUMLAH \\
\hline 1 & BARU BOGOR & 447 \\
\hline 2 & KEBON KEMBANG & 387 \\
\hline 3 & SUKASARI & 78 \\
\hline \multirow[t]{5}{*}{4} & MERDEKA & 60 \\
\hline & A. PEJAGALAN & 0 \\
\hline & B. DEVRIS & 0 \\
\hline & C. TAMAN & \\
\hline & KENCANA & 0 \\
\hline 5 & PADASUKA & 0 \\
\hline 6 & JAMBU DUA & 300 \\
\hline 7 & GUNUNG BATU & 50 \\
\hline 8 & TANAH BARU & 0 \\
\hline \multirow[t]{2}{*}{9} & PAMOYANAN & 0 \\
\hline & JUMLAH & 1322 \\
\hline & $\begin{array}{r}\text { Sumber : Busin } \\
\text { PD PPJ 2010 }\end{array}$ & \\
\hline
\end{tabular}

Dari tabel 1, dapat dilihat bahwa jumlah pedagang kaki lima di Pasar Kebon Kembang mencapai ratusan. Artinya harus adanya program penataan pedagang tersebut, tanpa menghilangkan hak mereka untuk berdagang.

2. Kebersihan dan keamanan pasar yang belum baik.

Pengelolaan kebersihan disetiap pasar, dilaksanakan oleh pihak ketiga, yaitu Koperasi Pasar. Pengelolaan kebersihan tersebut mewajibkan pihak ketiga untuk menciptakan kebersihan dan keindahan disetiap pasar. Akan tetapi sumber daya dan peralatan yang tidak mendukung sehingga berdampak kepada kebersihan disetiap pasar, seperti contoh Pasar Kebon Kembang yang memiliki 6 Blok dengan total luas $9.665 \mathrm{M}^{2}$, pelaksanaan kebersihan hanya dilaksanakan jumlah petugas kebersihan yang dapat dilihat pada tabel berikut : 
Tabel 2. Daftar Jumlah Petugas Kebersihan Pasar Kebon Kembang

\begin{tabular}{ccc}
\hline NO & BLOK & $\begin{array}{c}\text { PETUGAS } \\
\text { KEBERSIHAN }\end{array}$ \\
\hline 1 & Blok B1 & 3 Orang \\
\hline 2 & Blok B2 & 3 Orang \\
\hline 3 & Blok F & 4 Orang \\
\hline 4 & Blok G & 2 Orang \\
\hline 5 & Blok A & $\begin{array}{c}\text { (Masih Dalam } \\
\text { Revitalisasi) }\end{array}$ \\
\hline
\end{tabular}

Sumber : Unit Kebersihan Koperasi Pasar Kebon Kembang Periode 2014

Dari tabel 2, dapat diketahui bahwa jumlah petugas kebersihan tidak proporsional dengan banyaknya jumlah blok. Tentunya harus ada optimalisasi pemeliharaan kebersihan.

Sedangkan dari segi keamanan disetiap pasar, terdapat bagian operasional dengan tupoksi yaitu supervisi keamanan, ketertiban dan kebersihan serta pelaksana usaha jasa. Akan tetapi disetiap pasar, jumlah sumber daya serta peralatan kerja belum optimal. Hal ini bisa dilihat pada tabel berikut :

Tabel 3. Daftar Jumlah Pegawai Bagian Operasional di Tiap-Tiap Pasar

\begin{tabular}{|c|c|c|c|}
\hline NO & PASAR & $\begin{array}{c}\text { LUAS } \\
\text { AREA } \\
\text { PASAR } \\
\text { (M2) }\end{array}$ & $\begin{array}{c}\text { JUMLAH } \\
\text { PEGAWAI } \\
\text { BAGIAN } \\
\text { OPERASIONAL }\end{array}$ \\
\hline 1 & $\begin{array}{l}\text { Pasar } \\
\text { Baru } \\
\text { Bogor }\end{array}$ & - & 7 Orang \\
\hline 2 & $\begin{array}{l}\text { Plaza } \\
\text { Bogor }\end{array}$ & - & 30 Orang \\
\hline 3 & $\begin{array}{c}\text { Pasar } \\
\text { Kebon } \\
\text { Kembang }\end{array}$ & $\begin{array}{c}9.665 \\
M^{2}\end{array}$ & 23 Orang \\
\hline 4 & $\begin{array}{c}\text { Pasar } \\
\text { Merdeka }\end{array}$ & - & 7 Orang \\
\hline 5 & $\begin{array}{c}\text { Pasar } \\
\text { Jambu } \\
\text { Dua }\end{array}$ & $\begin{array}{c}6.124 \\
M^{2}\end{array}$ & 2 Orang \\
\hline 6 & $\begin{array}{c}\text { Pasar } \\
\text { Gunung } \\
\text { Batu }\end{array}$ & $\begin{array}{c}2.495 \\
M^{2}\end{array}$ & 4 Orang \\
\hline 7 & $\begin{array}{c}\text { Pasar } \\
\text { Sukasari }\end{array}$ & $\begin{array}{c}5.450 \\
\mathrm{M}^{2}\end{array}$ & 7 Orang \\
\hline
\end{tabular}

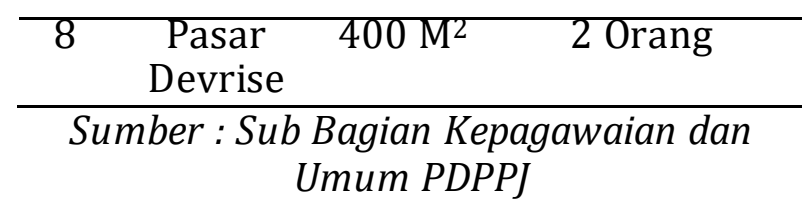

Dari tabel 3, dapat diketahui bahwa jumlah pegawai bagian operasional tidak proporsional dengan luas area pasar. Hal ini bisa berdampak pada keamanan dan pengamanan asset pasar.

3. Tidak berjalannya pemeliharaan fisik bangunan pasar.

Pemeliharaan pada fisik bangunan pasar menjadi faktor penting dalam hal pengelolaan pasar, sebab dengan melaksanakan pemeliharaan secara rutin dan berkala, akan berdampak pada umur fisik bangunan. Tentunya pekerjaan pemeliharaan akan dilaksanakan oleh bagian yang memiliki tupoksi yang berkaitan dengan pemeliharaan. Akan tetapi berdasarkan struktur pegawai disetiap pasar tidak terdapat bagian pemeliharaan seperti struktur pegawai pasar dibawah ini :

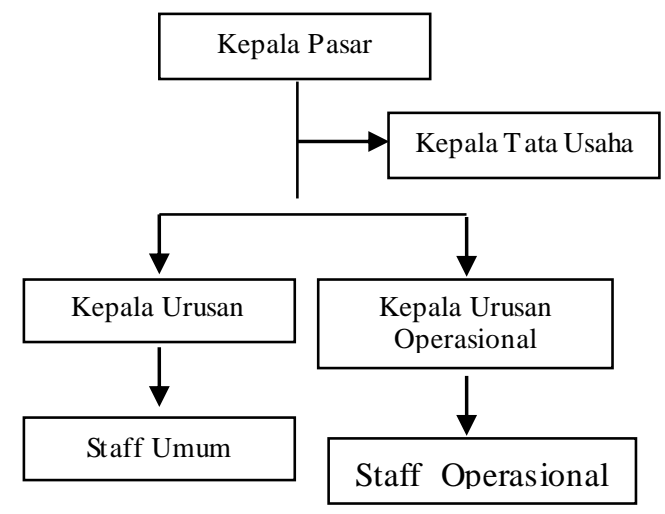

\section{Gambar 1. Struktur Pegawai Pasar di Lingkungan PD Pasar Pakuan Jaya}

Dari tugas kepala pasar tersebut diatas, dapat diketahui bahwa terjadi sebuah proses kebijakan publik, dimana kebijakan kepala pasar dapat dikategorikan sebagai kebijakan publik karena kepala pasar mengelola pasar yang notabene-nya adalah sebuah tempat publik/umum (Agustino, 2012:29). 


\section{MATERI DAN METODE}

\section{Lokasi dan Waktu Penelitian}

Penelitian ini dilakukan pada PD Pasar Pakuan Jaya Kota Bogor, Unit Pasar Kebon Kembang terletak di Jalan Dewi Sartika No. 10, Kota Bogor. Penelitian dilakukan mulai bulan November 2014 sampai dengan Maret 2015.

\section{Pendekatan Penelitian}

Pendekatan penelitian yang digunakan adalah Penelitian Deskriptif dan Pendekatan Kualitatif.

\section{Unit Analisis, Populasi, dan Sampel Penelitian}

Penelitian ini dilakukan di PD Pasar Pakuan Jaya Kota Bogor, Unit Pasar Kebon Kembang. Jumlah pegawai di tempat tersebut adalah 23 orang. Dengan demikian teknik pengambilan sampel yang digunakan dalam penelitian ini adalah teknik sampling jenuh (sensus). Menurut Sugiyono (2008: 62) istilah lain dari sampling jenuh adalah sensus, dimana semua anggota populasi dijadikan sampel.

Teknik pengumpulan data yang yang digunakan adalah studi lapangan dan studi literatur. Pengumpulan data dalam studi lapangan dilakukan dengan melakukan wawancara mendalam dan penyebaran kuesioner. Wawancara ditujukan kepada orang-orang atau pihak yang terlibat langsung dengan implementasi kebijakan kepala pasar di PD Pasar Pakuan Jaya Kota Bogor, seperti Direksi PD Pasar Pakuan Jaya Kota Bogor, Badan Pengawas PD Pasar Pakuan Jaya Kota Bogor dan Koperasi Pasar Kebon Kembang.

\section{Metode Analisa Data}

Dalam penelitian ini skala pengukurannya menggunakan rumus Bakrie Siregar (1981: 20) Weight Mean Score (WMS) yaitu dengan dilakukan pembobotan nilai untuk setiap jawaban, dengan interval 1-5, sehingga data dari pengisian kuesioner disajikan dalam bentuk distribusi frekuensi dan tabulasi silang serta data yang diperoleh berskala interval dan ordinal.
Data interval yang diperoleh antar kriteria, diperoleh dari rumus :

Nilai tertinggi - Nilai terendah Alternatif Jawaban

$$
\frac{5-}{\frac{1}{4}}=\underline{4}=0.8
$$

Dari rumus di atas maka interval antar kriteria nilainya adalah sebesar 0,8 sehingga dari ketentuan tersebut maka kriteria penafsirannya adalah :

Tabel 5.

Penafsiran antar kriteria

\begin{tabular}{ll}
\hline Interval Skor & Kriteria \\
\hline $1,00-1,80$ & Sangat Kurang Baik \\
\hline $1,81-2,60$ & Kurang Baik \\
\hline $2,61-3,40$ & Cukup Baik \\
\hline $3,41-4,20$ & Baik \\
\hline $4,21-5,00$ & Sangat Baik \\
\hline
\end{tabular}

Stanford Labovits Research dalam Siregar (1981: 35) digunakan untuk mengemukakan dan memperoleh angka penafsiran dipergunakan rumus :

$\mathrm{M}=\frac{\sum \mathrm{f}(\mathrm{x})}{\mathrm{n}}$

Dimana :

$\mathrm{M}=$ Perolehan angka kriteria penafsiran

$\mathrm{f}=$ Frekuensi Jawaban

$\mathrm{x}=$ Pembobotan (skala nilai)

$\Sigma=$ Penjumlahan

$\mathrm{n}=$ Jumlah sampel penelitian

Berdasarkan rumus di atas, penulis akan mentabulasi data sesuai dengan angka penafsiran antar kriteria, yakni sebagai

\begin{tabular}{|c|c|c|c|c|c|}
\hline No. & $\begin{array}{c}\text { Alternatif } \\
\text { Jawaban }\end{array}$ & 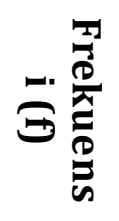 & 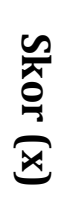 & $\underbrace{x}$ & $\begin{array}{l}\vec{x}_{3} \\
\underbrace{}_{M}\end{array}$ \\
\hline 1. & Sangat Baik & & 5 & & \\
\hline 2. & Baik & & 4 & & \\
\hline 3. & Cukup Baik & & 3 & & \\
\hline 4. & Kurang Baik & & 2 & & \\
\hline
\end{tabular}
berikut:

Tabel 6. Distribusi Skor 


\begin{tabular}{ll}
\hline $\begin{array}{l}\text { Sangat Tidak } \\
\text { Baik }\end{array}$ & 1 \\
\hline \multicolumn{2}{|}{ Jumlah $(\mathrm{n})=$} \\
\hline
\end{tabular}

Untuk menganalisis data nominal yang diperoleh secara deskriptif, penulis menggunakan analisis statistik deskriptif berupa frekuensi, presentase, rataan, rataan skor dan total rataan skor melalui rumus WMS (Weight Mean Score).

\section{HASIL DAN PEMBAHASAN}

\section{HASIL}

\section{Profil PD Pasar Pakuan Jaya Kota Bogor}

Perusahaan Daerah Pasar Pakuan Jaya (PD Pasar Pakuan Jaya) didirikan berdasarkan Peraturan Daerah (Perda) Kota Bogor Nomor 4 Tahun 2009 tentang "Pendirian Perusahaan Daerah Pasar Pakuan Jaya." Dan kemudian secara teknis Walikota Bogor tuangkan dalam Perwali Nomor 21 Tahun 2010 tertanggal 7 Juli 2009 yang diundangkan dalam Lembaran Daerah Kota Bogor Nomor 27 tahun 2009 tentang organisasi dan tata kerja PD Pasar Pakuan Jaya Kota Bogor tanggal 2 November 2009.

Untuk melakukan operasionalnya PD Pasar Pakuan Jaya di dukung oleh Peraturan Daerah No 7 Tahun 2010 tentang Penyertaan Modal Pemerintah Kepada Perusahaan Daerah Air Minum (PDAM) Tirta Pakuan, Perusahaan Daerah Bank Perkreditan Rakyat Bank Pasar, Perusahaan Daerah Jasa Transportasi, dan Perusahaan Daerah PD Pasar Pakuan Jaya Kota Bogor yang diundangkan dalam Lembaran Daerah Kota Bogor Tahun 2010 Nomor 5 Seri E. Dijabarkan oleh Perwali Nomor 15 tahun 2011 tentang Perubahan Atas Peraturan Walikota Bogor Nomor 21 Tahun 2010 tentang Petunjuk Pelaksana Peraturan Daerah Kota Bogor No 4 Tahun 2009 Tentang Pendirian Perusahaan Daerah Pasar Pakuan Jaya.

Sejalan dengan waktu, diterbitkannya Peraturan Daerah Kota Bogor Nomor 20 Tahun 2011 tentang Perubahan Atas Peraturan Daerah Kota Bogor Nomor 7
Tahun 2010 tentang Penyertaan Modal Pemerintah Kepada Perusahaan Daerah Air Minum (PDAM) Tirta Pakuan, Perusahaan Daerah Bank Perkreditan Rakyat Bank Pasar, Perusahaan Daerah Jasa Transportasi, dan Perusahaan Daerah PD Pasar Pakuan Jaya Kota Bogor yang diundangkan dalam lembaran daerah Kota Bogor tahun 2011 nomor 8 seri E.

Tujuan dan Fungsi didirikannya PD Pasar Pakuan Jaya sebagaimana tercantum dalam Peraturan Daerah Nomor 4 Tahun 2009 tentang Pendirian Perusahaan Daerah Pasar Pakuan Jaya adalah:

a) meningkatkan pelayanan kebutuhan sarana dan prasarana pasar yang nyaman, bersih dan teratur;

b) mendorong perekonomian daerah;

c) menunjang pembangunan daerah;

d) meningkatkan profesionalitas dan efisiensi pengelolaan pasar;

e) meningkatkan Pendapatan Asli Daerah.

Sesuai Peraturan Daerah (Perda) Kota

Bogor Nomor 4 Tahun 2009 tentang Pendirian Perusahaan Daerah Pasar Pakuan Jaya dan Keputusan Walikota Bogor No 591.45-14 Tahun 2012 tentang Penunjukan Perusahaan Daerah Pakuan Jaya (PD PPJ) Kota Bogor Sebagai Pengelola Pasar di Lingkungan Pemerintah Kota Bogor, PD Pasar Pakuan Jaya saat ini mengelola (1) Pasar Bogor, (2) Pasar Merdeka termasuk (a) Pasar Devris, (b) Pasar Taman Kencana, dan (c) Pasar Pajagalan (3) Pasar Sukasari, (4) Pasar Jambu Dua, Pasar Kebon Kembang, (5) Gunung Batu, (6) Pasar Padasuka, (7) Pasar Pamoyanan, (8) Pasar Tanah Baru. Secara lengkap seperti dalam tabel-tabel dibawah ini :

\section{Tabel 7. JUMLAH KIOS BUKA TAHUN 2012}

\begin{tabular}{rlccc}
\hline No & PASAR & \multicolumn{3}{c}{ KIOS } \\
\hline & & B & T & JUM \\
\hline 1 & Baru Bogor & 1186 & 785 & 1971 \\
\hline & Kebon & & & \\
2 & Kembang & 651 & 167 & 818 \\
\hline 3 & Sukasari & 234 & 25 & 259 \\
\hline
\end{tabular}




\begin{tabular}{llrrr}
4 & Merdeka & 275 & 209 & 484 \\
\hline $\begin{array}{l}\text { a. } \\
\text { Pejagalan }\end{array}$ & 23 & 1 & 24 \\
\hline & b. Devris & 10 & 3 & 13 \\
\hline & c. Taman & & & \\
& Kencana & 15 & 0 & 15 \\
\hline 5 & Padasuka & 30 & 14 & 44 \\
\hline 6 & Jambu Dua & 0 & 0 & 0 \\
\hline & Gunung & & & \\
7 & Batu & 101 & 35 & 136 \\
\hline 8 & Tanah Baru & 2 & 10 & 12 \\
\hline 9 & Pamoyanan & 0 & 72 & 72 \\
\hline & JUMLAH & $\mathbf{2 5 2 7}$ & $\mathbf{1 3 2 1}$ & $\mathbf{3 8 4 8}$ \\
\hline
\end{tabular}

Sumber : Bussiness Plan PD Pasar Pakuan Jaya Tahun 2011-2015

Tabel 8. JUMLAH LOS BUKA TAHUN 2012

\begin{tabular}{llrrr}
\hline No & PASAR & \multicolumn{2}{c}{ LOS } \\
\hline & & B & \multicolumn{1}{c}{ T } & \multicolumn{1}{c}{ JUM } \\
\hline 1 & Baru Bogor & 130 & 150 & 280 \\
\hline & Kebon & & & \\
2 & Kembang & 700 & 821 & 1521 \\
\hline 3 & Sukasari & 19 & 29 & 48 \\
\hline 4 & Merdeka & 242 & 0 & 242 \\
\hline & a. & & & \\
& Pejagalan & 0 & 0 & 0 \\
\hline & b. Devris & 10 & 0 & 10 \\
\hline & c. Taman & & & \\
& Kencana & 0 & 0 & 0 \\
\hline 5 & Padasuka & 88 & 16 & 104 \\
\hline 6 & Jambu Dua & 240 & 480 & 720 \\
\hline & Gunung & & & \\
7 & Batu & 48 & 28 & 76 \\
\hline 8 & Tanah Baru & 3 & 117 & 120 \\
\hline 9 & Pamoyanan & 0 & 0 & 0 \\
\hline & JUMLAH & $\mathbf{1 4 8 0}$ & $\mathbf{1 6 4 1}$ & $\mathbf{3 1 2 1}$ \\
\hline
\end{tabular}

Sumber : Bussiness Plan PD Pasar Pakuan Jaya Tahun 2011-2015

Ket:

B: Buka T: Tutup JUM: Jumlah

\section{Visi Misi PD Pasar Pakuan Jaya Kota Bogor}

Perusahaan Daerah Pasar Pakuan Jaya memiliki Visi sebagai berikut "Penyedia Jasa Layanan Pasar yang Adaptif, Kemitraan dan Berkesinambungan guna mencapai Perusahaan Daerah yang Sehat dan Prosfektif di Tahun 2015“.

Adaftif, bermakna bahwa PD Pasar Pakuan Jaya dalam penyediaan jasa layanan pasar harus bersinergi dengan perubahan lingkungan mikro dan makro dalam jenis dan pola pelayanan pasar sehingga meningkat posisi tawar dalam dunia layanan pasar terhadap masyarakat yang sejalan waktu berkembang pesat dalam lingkup dunia usaha.

Kemitraan, bermakna bahwa PD Pasar Pakuan Jaya dalam menjalankan perusahaan harus mampu meningkatan kualitas dan kuantitas jasa layanan pasar dengan melibatkan sumber daya lokal, sumber daya non-Perusahaan, dan Networking yang terdapat di lingkungan pasar khususnya dan lingkungan masyarakat pada umumnya sehingga entitas pasar menjadi milik bersama guna mewujudkan kesejahtraan perekonomian lokal dan regional.

Berkesinambungan, bermakna bahwa PD Pasar Pakuan Jaya dalam ruang waktu, media dan kondisi apapun harus selalu meningkatkan kualitas dan Kuantitas Jasa layanan pasar secara perodik, terukur dan target yang jelas guna menjamin keberlangsungan proses transaksi ekonomi di pasar yang berkelanjutan sehingga menjamin keberlangsungan PD Pasar Pakuan Jaya dan peningkatan usaha stakeholder di lingkungan pasar.

Out put terselenggaranya visi tersebut bermuara pada PD Pasar Pakuan Jaya yang Sehat secara sistem, manajerial, keuangan, dan usaha yang pada akhirnya menjadikan PD Pasar Pakuan Jaya sebagai Perusahan Daerah Prospektif yang memiliki peluang untuk berkembang dan melakukan ekspansi usaha guna memberikan kontribusi pembangunan bagi perusahaan, pemerintah dan masyarakat Kota Bogor.

Untuk mewujudkan Visi tersebut di atas PD Pasar Pakuan Jaya menetapkan misinya sebagai berikut :

1. Meningkatkan manajemen kinerja perusahaan melalui pengembangan 
kapasitas manajemen, profesionalisme pegawai, dan sistem korporasi

2. Meningkatkan kuantitas dan kualitas aset perusahaan melalui revitalisasi, sertifikasi dan kapitalisasi aset

3. Meningkatkan fungsi pasar melalui penciptaan sentra sentra pertumbuhan transaksi pasar yang sesuai dengan potensi lokal dan spesifik/tematik

Meningkatkan peran serta stakeholder pasar melalui kemitraan usaha dalam menjamin distribusi barang dan jasa, menciptakan ketertiban keamanan kebersihan terpadu, peningkatan kuantitas dan kualitas transaksi, serta upaya pemberdayaan pedagang dalam setiap aktivitas di lingkungan pasar.

\section{Kepala Pasar}

Di dalam Peraturan Direksi PD Pasar Pakuan Jaya No. 1.2.1 Tahun 2012 tentang Tugas Pokok dan Fungsi serta Uraian Jabatan di Lingkungan Perusahaan Daerah Pasar Pakuan Jaya Kota Bogor pada Pasal 31 Bagian Keenam point kedua, adalah Tugas Pokok dan Fungsi Kepala Pasar yaitu

a. Membuat daftar aset yang dimiliki unit.

b. Membuat, menyampaikan dan mempertanggung jawabkan pengajuan biaya-biaya unit pasar.

c. Melaksanakan perencanaan dan mengembangkan potensi usaha di lingkungan unit pasar sesuai program kerja perusahaan.

d. Membuat laporan kegiatan unit pasar secara periodik kepada Direksi.

e. Membuat rencana kerja dan anggaran kegiatan untuk unit pasar masingmasing.

f. Perencanaan kebutuhan peralatan penunjang pelaksanaan ketertiban, kebersihan, dan keamanan pasar.

g. Membuat laporan kegiatan ketertiban, keamanan, dan kebersihan unit pasar.

h. Membuat laporan kegiatan pemeliharaan secara periodik.

i. Mengajukan usul rencana pemeliharaan di unit pasar. j. Membuat rencana dan laporan kegiatan Bidang Tata Bangunan.

Sedangkan Wewenang Kepala Pasar dalam Peraturan Direksi PD Pasar Pakuan Jaya No.1.2.1 Tahun 2012 tentang Tugas Pokok dan Fungsi serta Uraian Jabatan di Lingkungan Perusahaan Daerah Pasar Pakuan Jaya Kota Bogor pada Pasal 31 Bagian Keenam point kedua, adalah sebagai berikut :

a. Mengkoordinasikan, melaksanakan dan mengendalikan kegiatan teknis dari Kepala Bagian atau Sub Bagian atas persetujuan Direksi.

b. Melakukan pembinaan kepada staf dan pedagang yang ada dilingkungannya.

c. Mengurus dan mengelola kekayaan unit.

d. Menyelenggarakan administrasi umum dan keuangan.

e. Menerima dan menyetorkan semua penerimaan unit ke kantor pusat melalui bank yang ditunjuk.

f. Melakukan koordinasi dengan Muspika dan pihak terkait.

g. Melaksanakan pencapaian target sesuai dengan Rencana Kerja dan Anggaran Perusahaan (RKAP).

h. Merencanakan, mengkoordinasi, mengevalusasi kegiatan para staf unit.

i. Melaksanakan kegiatan usaha jasa PD Pasar Pakuan Jaya.

j. Pelaksana teknis kegiatan pemeliharaan di unit pasar.

k. Melaksanakan penyelesaian masalah yang berhubungan pemeliharaan sarana prasarana pasar.

l. Meneliti dan memeriksa serta memproses usulan perawatan bangunan yang di ajukan oleh kepala unit pasar.

\section{Analisa Data}

Untuk mengetahui seberapa besar kriteria penilaian implementasi kebijakan yang dilakukan oleh Kepala Pasar Kebon Kembang, maka dilakukan penyebaran kuesioner kepada 23 orang pegawai Pasar Kebon Kembang. Kemudian data dari 
pengisian kuesioner disajikan dalam tabel 8.

Tabel 8. Hasil Rekapitulasi Berdasarkan Indikator Variabel Implementasi

Kebijakan Kepala Pasar dalam Program K3 (Kebersihan, Keamanan dan

Ketertiban) di Perusahaan Daerah Pasar Pakuan Jaya Kota Bogor

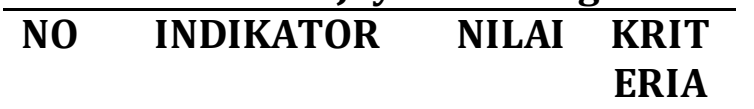

\begin{tabular}{|c|c|c|c|}
\hline 1 & $\begin{array}{l}\text { Kebijakan } \\
\text { Kepala Pasar } \\
\text { dalam Progam } \\
\text { K3 (Kebersihan, } \\
\text { Keamanan dan } \\
\text { Ketertiban) } \\
\text { sesuai dengan } \\
\text { standard dan } \\
\text { tujuan } \\
\text { Perusahaan } \\
\text { Daerah Pasar } \\
\text { Pakuan Jaya } \\
\text { Kota Bogor }\end{array}$ & 3,78 & Baik \\
\hline 2 & $\begin{array}{l}\text { Sumber Daya } \\
\text { yang ada cukup } \\
\text { dan memenuhi } \\
\text { persyaratan } \\
\text { untuk } \\
\text { mengimplement } \\
\text { asikan kebijakan } \\
\text { Kepala Pasar }\end{array}$ & 2,87 & $\begin{array}{c}\text { Cuku } \\
\mathrm{p} \\
\text { Baik }\end{array}$ \\
\hline 3 & $\begin{array}{l}\text { Kebijakan } \\
\text { Kepala Pasar } \\
\text { dalam Program } \\
\text { K3 dikomunikasi } \\
\text { lintas } \\
\text { instansi/lembag } \\
\text { a dengan baik }\end{array}$ & 2,95 & $\begin{array}{c}\text { Cuku } \\
\text { Baik }\end{array}$ \\
\hline 4 & $\begin{array}{l}\text { Para Pegawai } \\
\text { sama persepsi } \\
\text { dengan } \\
\text { kebijakan Kepala } \\
\text { Pasar }\end{array}$ & 3,78 & Baik \\
\hline 5 & $\begin{array}{l}\text { Kepala Pasar } \\
\text { mengetahui dan } \\
\text { memahami } \\
\text { terhadap } \\
\text { kebijakan yang } \\
\text { dibuat }\end{array}$ & 3,61 & Baik \\
\hline
\end{tabular}

\begin{tabular}{|c|c|c|c|}
\hline 6 & $\begin{array}{l}\text { Kondisi sosial, } \\
\text { ekonomi dan } \\
\text { politik tidak } \\
\text { mempengaruhi } \\
\text { Kebijakan } \\
\text { Kepala Pasar }\end{array}$ & 1,83 & $\begin{array}{l}\text { Kuran } \\
\text { g Baik }\end{array}$ \\
\hline & Jumlah & 18,8 & \\
\hline & $\sum=18,8 / 6$ & 3,13 & $\begin{array}{c}\text { Cuku } \\
\mathbf{p} \\
\text { Baik }\end{array}$ \\
\hline
\end{tabular}

Sumber: Hasil Penelitian 2015

Berdasarkan tabel rekapitulasi diatas, maka dapat disimpulkan bahwa variabel implementasi kebijakan Kepala Pasar dalam program K3 (Kebersihan, Keamanan dan Ketertiban) secara keseluruhan sudah dilaksanakan dengan cukup baik, hal ini dikaitkan dengan kriteria penilaian yang memperoleh nilai rata-rata 3,13 berarti pada interval 2,61 sampai dengan 3,40 yang berarti mempunyai kriteria cukup baik.

\section{Implementasi Kebijakan Kepala Pasar Kebon Kembang}

Kepala Pasar sebagai pelaksana teknis di wilayahnya, dapat mengeluarkan atau membuat kebijakan seperti dalam hal manajemen unit yang dipimpinnya. Berikut adalah kebijakan teknis k3 yang di implementasikan yaitu pelaksanaan sistem piket K3 (Kebersihan, Keamanan dan Ketertiban), pelaksanaan penertiban pedagang, pelaksanaan supervisi kebersihan, pelaksanaan penagihan service charge, dan pelaksanaan koordinasi dengan pihak kelurahan, babinsa dan babinmas.

\section{Hambatan Implementasi Kebijakan Kepala Pasar Kebon Kembang}

Pasar Kebon Kembang memiliki gedung atau blok sebanyak 5 unit yaitu Blok A, B1, B2, F dan G. Total luas bangunan $15.650 \mathrm{M}^{2}$ dan total luas tanah $9.665 \mathrm{M}^{2}$. Dengan luas tersebut, banyak hambatan yang dihadapi Kepala Pasar sebagai pimpinan Unit Pasar 
Kebon Kembang. Adapun hambatan 1. PD Pasar Pakuan Jaya Kota Bogor adalah tersebut adalah :

1. Personil k3 tidak mencukupi/tidak sebanding dengan luas area pasar. Dengan total bagian operasional sebanyak 15 orang atau per-shiftnya dengan total 5 personil yang bertugas, tentu ini tidak proporsional dengan jumlah luasan gedung dan tanah Pasar Kebon Kembang.

2. Pelaksanaan kebersihan oleh pihak ketiga tidak maksimal.

3. Tugas tambahan sebagai penagih service charge berdampak pada jumlah personil K3 yang bertugas.

\section{Upaya yang dilakukan Kepala Pasar}

Upaya yang dilakukan Kepala Pasar untuk mengimplementasikan kebijakan dalam hal program K3 (Kebersihan, Keamanan dan Ketertiban) adalah sebagai berikut :

1. Sesuai dengan tugas pokok dan fungsi Kepala Pasar, maka Kepala Pasar dapat mengajukan tambahan personil atau pegawai bagian operasional untuk sistem piket K3 (Kebersihan, Keamanan dan Ketertiban), sehingga tugas sistem tersebut dapat bertambah lebih baik.

2. Pemberlakuan Peraturan Walikota Nomor 4 Tahun 2010 tentang Tata Cara Penerbitan Buku Hak Pemakaian Tempat Berdagang (BHPTB) dan Kartu Izin Pemakaian Tempat Berdagang (KIPTB) di Pasar Pemerintah Kota Bogor.

\begin{abstract}
Melakukan kajian dan evaluasi pelaksanaan kebersihan serta berkoordinasi terkait kebersihan Pasar Kebon Kembang, baik dari sistem dan sumber daya manusia yang ada.
\end{abstract}

\section{KESIMPULAN DAN IMPLIKASI}

\section{Kesimpulan}

Dari hasil pengumpulan data dan hasil analisisnya, maka penulis menarik beberapa kesimpulan sebagai berikut :
Perusahaan Daerah yang mengelola seluruh pasar yang berada dibawah milik Pemerintah Kota Bogor. PD Pasar Pakuan Jaya Kota Bogor dalam pengelolaannya menggunakan program K3 (Kebersihan, Keamanan dan Ketertiban) untuk menwujudkan pasar yang aman, nyaman dan bersih.

Ada enam faktor yang berpengaruh terhadap keberhasilan atau kegagalan implementasi kebijakan kepala pasar dalam program K3 (Kebersihan, Keamanan dan Ketertiban), diantaranya adalah standar dan tujuan kebijakan, sumber daya kebijakan, komunikasi antar organisasi dan aktivitas pelaksanaan, karakteristik badan/instansi pelaksana kebijakan, sikap pelaksana kebijakan, kondisi sosial ekonomi dan politik.

Implementasi kebijakan kepala pasar dalam program K3 (Kebersihan, Keamanan dan Ketertiban) yaitu pelaksanaan sistem piket K3 (Kebersihan, Keamanan dan Ketertiban), pelaksanaan penertiban pedagang, pelaksanaan supervisi kebersihan, pelaksanaan penagihan service charge, dan pelaksanaan koordinasi dengan pihak kelurahan, babinsa dan babinmas.

Dilihat dari perhitungan Weight Mean Score (WMS) dengan mengambil sampel sebanyak 23 pegawai dan diperoleh kriteria penilaian yang memperoleh nilai rata-rata 3,14 berarti pada interval 2,61 sampai dengan 3,40 yang berarti mempunyai kriteria cukup baik. Maka dapat disimpulkan bahwa implementasi kebijakan Kepala Pasar dalam program K3 (Kebersihan, Keamanan dan Ketertiban) secara keseluruhan sudah dilaksanakan dengan cukup baik

\section{Implikasi}

Adapun implikasi dari penulis adalah Kebijakan Kepala Pasar harus sesuai dengan pengelolaan pasar yang ideal yaitu mewujudkan pasar yang aman, nyaman dan bersih.

Adanya aturan atau payung hukum yang dibuat oleh PD Pasar Pakuan Jaya 
Kota Bogor perihal program K3

(Kebersihan, Keamanan dan Ketertiban).

\section{DAFTAR PUSTAKA}

Agustino, Leo. 2012. Dasar-Dasar Kebijakan Publik. Bandung : Alfabeta.

Bussiness Plan PD Pasar Pakuan Jaya Kota Bogor Tahun 2011-2015.

Labovits, Sanford, et al.1982. Metode Riset Sosial: Suatu Pengantar, terjemahaan oleh Bakri Siregar dari judul asli Introduction to Social Research (1981). Jakarta: Penerbit Erlangga.

Peraturan Daerah No. 4 Tahun 2009 tentang Pendirian Perusahaan Daerah Pakuan Jaya.

Peraturan Walikota Kota Bogor No. 27 tahun 2009 tentang Organisasi dan Tata Kerja PD Pasar Pakuan Jaya.

Peraturan Direksi PD Pasar Pakuan Jaya No. 1.2.1 Tahun 2012 tentang Tugas Pokok dan Fungsi serta Uraian Jabatan di Lingkungan Perusahaan Daerah Pasar Pakuan Jaya Kota Bogor.

Sugiyono. 2008. Metode Penelitian Kunatitatif Kualitatif dan R\&D. Bandung : Alfabeta. 